\title{
Segregation of Distinct Variants from Citrus tristeza virus Isolate SY568 Using Aphid Transmission
}

\author{
J. J. Velazquez-Monreal, D. M. Mathews, and J. A. Dodds
}

Department of Plant Pathology and Microbiology, University of California, Riverside 92521.

Current address of J. J. Velazquez-Monreal: INIFAP-Colima, Apdo. Postal 88, Tecoman, Colima, 28100, Mexico. Accepted for publication 27 May 2009.

\begin{abstract}
Velazquez-Monreal, J. J., Mathews, D. M., and Dodds, J. A. 2009. Segregation of distinct variants from Citrus tristeza virus isolate SY568 using aphid transmission. Phytopathology 99:1168-1176.

A well-studied severe isolate of Citrus tristeza virus (CTV) known as SY568 has previously been shown to contain multiple variants of the virus which differ in their genetic and biological characters. Aphid transmission was used in an attempt to segregate some of these variants for further characterization. Resulting infections gave symptoms which varied from asymptomatic to more severe than the inoculum source. RNase protection assays (RPAs) were used to compare nine regions of the

then cloned, sequenced, and compared with known isolates. An asymptomatic strain was shown to be different in every area of the CTV genome when examined by RPA and sequencing of selected regions. Mixedinfection studies using graft transmission of the asymptomatic subculture and two of the more severe aphid-transmitted subcultures showed that the mild strain was not able to compete well when in the presence of any of the severe variants tested, and its titer was significantly reduced from that seen in single infection. The mild strain and a selected severe strain were singly graft inoculated into five different citrus hosts (sweet orange, grapefruit, sour orange, lemon, and lime), where they maintained their distinct biological and genetic characteristics.
\end{abstract} CTV genome and determine whether unique strains could be identified. Five aphid-transmitted subcultures, with fingerprints that were different from those of the inoculum sources in at least one genomic area, were
Additional keywords: Aphis gossypii, Closterovirus.
Citrus tristeza virus (CTV) is the causal agent of the most important viral disease of citrus worldwide and induces a range of symptoms on infected plants, including quick decline, seedling yellows, stunting, vein corking, and stem pitting $(5,27)$. The genome consists of an average of 19,250 plus-sense RNA nucleotides which code for at least 12 open reading frames and is encapsidated into 2,000-nm flexuous rods. The CTV isolate SY568 is an especially severe isolate originally found in the citrus cultivar collection at the University of California, Riverside (10). Our laboratory has maintained this isolate under greenhouse conditions for the past 25 years, and throughout this period it has maintained its severity. Isolate SY568 has formed the basis of extensive research, including host-range and attenuation studies, as well as genetic characterization and complete sequencing (GenBank accession no. AF001623) (18,20,46,55). Host-range studies have shown that SY568 can induce severe reactions that include vein corking, stunting, and extreme stem pitting in Madam Vinous sweet orange (Citrus sinensis (L.) Osbeck); extensive vein corking in leaves of Mexican lime ( $C$. aurantifolia (Christm.) Swingle.); severe stunting in grapefruit and in sweet orange grafted on sour orange; as well as intense seedling yellows in grapefruit, lemon, sweet orange, and sour orange seedlings $(18,20,46)$.

Isolate SY568 has been shown to be a mixture of several strains or variants with different genetic profiles, including at least one mild strain among severe variants that are responsible for the extreme biological symptoms seen in most hosts $(51,55)$. For the purposes of this article, a plant containing an original, unmodified source of CTV will be referred to as an "isolate" while "sub-

Corresponding author: D. M. Mathews; E-mail address: dmathews@ucr.edu

doi:10.1094/PHYTO-99-10-1168

(C) 2009 The American Phytopathological Society isolate" will be used to describe a CTV infection that has been derived from an isolate by either graft or aphid transmission. "Strains" of CTV have significant distinguishing genetic and biological characteristics, whereas "variants" may have one or more detectable differences while maintaining similarities with others in an isolate without the higher level of discrimination necessary to be a strain. Both isolates and subisolates may contain mixtures of strains or be composed of several genetic variants. Graft transmission has resulted in the recovery of SY568 subisolates that showed some segregation of detectable variants based on symptomatology and RNase protection assay (RPA) fingerprints (53). RPAs are useful when screening large numbers of isolates to look for sequence variations within specific areas of a genome, without having to clone and sequence.

Separation of CTV variants and strains has been reported in several studies using aphids $(1,8,9,16,19,21)$, and isolate SY568 has been shown to be readily transmitted by Aphis gossypii Glover $(44,45)$. In this study, subisolates of SY568 obtained through graft transmission were used as inoculum sources for aphid transmission using A. gossypii. The characterization of resulting subisolates and variants, including the hoped-for mild strain, is reported here.

\section{MATERIALS AND METHODS}

Virus subisolates. The original SY568 isolate was obtained from a stunted and stem-pitted Minneola tangelo in California (10). It was graft transmitted and has since been maintained in sweet orange under greenhouse conditions. A Duncan grapefruit (C. paradisi Macfad.) graft inoculated with SY568 (20) was used as an inoculum source to graft inoculate a series of Madam Vinous sweet orange plants in 1992 and 1996, resulting in a collection of 54 subisolates $(52,53)$. Three of these subisolates $(1 \mathrm{~B}, 11 \mathrm{~A}$, and $18 \mathrm{~A})$ were selected due to differences in symp- 
tomatology and variable RPA profiles and used as inoculum sources for aphid transmission experiments. Plants infected with subisolate 11A were severely stunted, with "honeycomb" pitting, while those infected with subisolate $18 \mathrm{~A}$ were as tall as the healthy control tree, with abundant but shallow stem pitting. Neither 11A nor 18A contained detectable amounts of the proposed mild strain from the SY568 isolate based on RPA using the p65 probe. Subisolate $1 \mathrm{~B}$ was predicted by RPA to contain both the mild strain and one or more severe variants, and infected plants had an intermediate height, with moderate, deep stem pitting.

Aphid vector and transmission experiments. A virus-free $A$. gossypii Glover colony was used for all aphid-transmission experiments. The insects were reared in cages on either healthy cucumber plants (Cucumis sativus var. Bush Pickle) or zucchini squash plants (Cucurbita pepo L. var. Chefini) (Henry Field Seed and Nursery Co., Shenandoah, IA) within an insectary at $24^{\circ} \mathrm{C}$ with a 16-h light period. The methodology for aphid inoculation was based partly on that described by Roistacher (43). Aphids were removed for acquisition by cutting leaves containing aphids into strips (5 to $7 \mathrm{~mm}$ wide) and placing them in two-piece cylindrical cages. Cages then were attached to young flushes of the inoculum source with rubber bands and staked into position, allowing an acquisition period of $24 \mathrm{~h}$ at $24^{\circ} \mathrm{C}$. Cages were removed and those aphids found feeding on the young leaves of the inoculum source were transferred to the healthy host receptor plants using a fine artist's brush. Madam Vinous sweet orange seedlings were used as host receptor plants; seedlings were 6 to 18 months old and planted two or three seedlings per pot. For each transmission experiment, 1, 10, or 30 aphids were transferred to the young, tender leaves of each receptor sweet orange seedling using either the two-piece cylindrical cages mentioned above or a plexiglass cylinder sealed at the top with a fine-mesh fabric that enclosed the entire receptor seedling. After an inoculation access period of $24 \mathrm{~h}$ at $24^{\circ} \mathrm{C}$, the cages were removed and the aphids were killed with an aphicide. Test seedlings were transferred to a greenhouse at temperatures of 28 to $32^{\circ} \mathrm{C}$ average daytime maximum and 14 to $22^{\circ} \mathrm{C}$ average nighttime minimum, and observed for typical tristeza symptoms, which usually started to appear 30 to 35 days postinoculation (dpi). Leaves were harvested for detection of CTV by enzymelinked immunosorbent assay (ELISA) at 50 and/or 100 dpi. These aphid-transmitted subisolates were analyzed further by RPA for molecular fingerprinting and, based on the results, some were selected and used for additional experiments. Transmission efficiencies were calculated and expressed as a percentage of the total number of plants inoculated with viruliferous aphids.

Biological indexing studies. Two of the aphid-transmitted subisolates were selected and used as inoculum sources for biological indexing experiments using Madam Vinous sweet orange, Duncan grapefruit, Mexican lime, Eureka lemon ( $C$. limon (L.) Burm. f.), and Standard sour orange (C. aurantium L.). Seedlings were trained to a single leading shoot and, when the stem was $\approx 1$ to $1.5 \mathrm{~cm}$ in diameter, the seedlings were cut back to an average height of $35 \mathrm{~cm}$ above the level of the soil prior to inoculation. Three to five seedlings (replications) were each inoculated with three patch grafts of young green bark from one of the two inoculum sources. Seedlings were observed periodically, symptoms were recorded, and the seedlings were analyzed by RPA 4 months after graft inoculation.

Graft-inoculated mixed-infection experiments. Madam Vinous sweet orange seedlings were trained to a single leader and cut back as described above. Three aphid-transmitted subisolates from subisolate 1B (1B-a4, -a10, and -a17) were selected as inoculum sources. Each was inoculated singly and as mixed infections of two sources (1B-a4 mixed with each of the other two subisolates). Two patch grafts of each inoculum source were used per plant (total of four grafts for the mixed infections of two subisolates). All plants were observed for symptoms regularly, infection was confirmed by ELISA $30 \mathrm{dpi}$, and the plants were then analyzed by RPA.

ELISA. Pooled petioles from leaves (4 to 10 per plant) were used for double-antibody sandwich, indirect ELISA (17) and RPAs (see below). Antigen samples were prepared by grinding

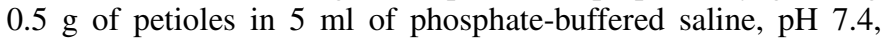
containing $2 \%$ polyvinylpyrrolidone and $0.5 \%$ Tween 20 . For some ELISA tests done on small sweet orange plants to detect CTV infection by aphid transmission, pooled apical half leaves (10-12) were used and the procedure was adapted to use $0.3 \mathrm{~g}$ of leaf blades and midribs instead of $0.5 \mathrm{~g}$ of petioles. Leaf blade and midrib tissue was also used to supplement samples from stunted plants when $0.5 \mathrm{~g}$ of petioles was not available. Two types of ELISA were used, with all plates being coated with a goat antiCTV polyclonal antibody prior to incubation with antigens prepared above. For general screening, a polyclonal rabbit antiCTV antibody made from a CTV coat protein-fusion protein construct was used as the secondary antibody (courtesy of D. J. Gumpf), followed by a commercial goat anti-rabbit-immunoglobulin $\mathrm{G}$ (IgG) alkaline phosphatase enzyme conjugate (SigmaAldrich, St. Louis, MO) and development with p-nitrophenyl phosphate as the substrate. To screen for potential severe strains, a second ELISA system was used, which substituted monoclonal antibody MCA 13 (courtesy of S. Garnsey) as the secondary antibody and a commercial goat anti-mouse-IgG linked to alkaline phosphatase as the enzyme conjugate (Boehringer Mannheim Biochemicals, Indianapolis, IN). MCA 13 detects decline inducing strains from Florida and generally more severe strains from California, including SY568 $(12,38)$.

RPAs. Nine different regions of the CTV genome were analyzed: 5' untranslated region (UTR), 5A polyprotein, RNAdependent RNA polymerase (RdRp), p65 heat-shock protein homolog (p65HSP), minor coat protein $(\mathrm{CPm})$, coat protein $(\mathrm{CP})$, p13, p20, and 3' UTR (plasmid constructs courtesy of T. E. Mirkov, Texas A\&M University) (Table 1). RNA transcripts labeled with ${ }^{32} \mathrm{P}-\mathrm{UTP}$ were produced from plasmids containing the nine genomic regions. Target RNAs were prepared from total nucleic acid (TNA) extracts purified through Sephadex G-50-80 columns and concentrated by ethanol precipitation (32). Final pellets were resuspended in sterile water and used immediately

TABLE 1. Specifications of RNase protection assay probes from cDNA clones of Citrus tristeza virus (CTV) isolate SY568

\begin{tabular}{lcccc}
\hline Probe $^{\text {a }}$ & $\begin{array}{c}\text { Size of probe alone in } \\
\text { nucleotides (nt) }\end{array}$ & $\begin{array}{c}\text { Size of probe protected by plus- } \\
\text { sense transcript (nt) }\end{array}$ & $\begin{array}{c}\text { CTV viral sequences contained } \\
\text { in probe (nt) }\end{array}$ & $\begin{array}{c}\text { Position of probe in SY568 } \\
\text { genome (nt) }\end{array}$ \\
\hline 5' UTR $^{\prime}$ 5A polyprotein & 166 & 130 & 120 & $8-128$ \\
RdRp & 635 & 599 & 557 & $996-1,553$ \\
p65HSP & 939 & 908 & 886 & $9,230-10,115$ \\
minor CP & 735 & 696 & 655 & $13,225-13,878$ \\
CP & 933 & 903 & 854 & $15,403-16,257$ \\
p13 & 450 & 403 & 361 & $16,256-16,616$ \\
P20 & 428 & 389 & 384 & $17,224-17,607$ \\
$3^{\prime}$ UTR & 633 & 586 & 552 & $17,737-18,288$ \\
\end{tabular}

${ }^{\mathrm{a}} \mathrm{UTR}=$ untranslated region, $\mathrm{RdRp}=\mathrm{RNA}$-dependent RNA polymerase, $\mathrm{HSP}=$ heat-shock protein, and $\mathrm{CP}=$ coat protein . 
for hybridizations. When multiple probes were being tested on the same samples on the same day, large aliquots of purified TNAs were prepared to ensure consistency of the target RNAs between probes. Additional aliquots of each TNA were stored in ethanol at $-80^{\circ} \mathrm{C}$ for future use. Probe production, hybridizations, and analysis were done as previously described $(26,54)$.

PCR and cloning of selected regions of the genome. Primers flanking the 5A, RdRp, and p65HSP genomic regions used for RPA were designed in order to amplify the sequences using reverse-transcription polymerase chain reactions (RT-PCRs). Single-tube RT-PCRs were performed as described previously (32) with the exception of using only 30 cycles. RNA targets used were from stored aliquots of TNA used in previous RPA experiments to ensure valid comparisons of the results. PCR primers for each region included $5 \mathrm{~A}$ polyprotein, 5A-1: $5^{\prime}-$ GCATGGCACAACTCATC-3' (complement) and 5A-2: 5'-CGTACGGTTTCTCCCCGCAA-3' (sense); RdRp, R-1: 5'-AGTAGCTCGAACTTTGAGAC-3' (complement, 51) and R-2: 5'-GAATATAAGGGTAGYAAAGCATC-3' (sense); and p65HSP, 65-1: 5'-CTAACTCGTTCTCGAAAGTC-3' (complement) and 65-2: 5'-GAGTGCTTAGATGGTAGGTC-3' (sense). Immediately after the PCR reactions were finished, the amplicons were checked by electrophoresis on a $1.5 \%$ agarose gel for size and quantitation, ligated into the vector pCR2.1 overnight, and used to transform Escherichia coli cells following the manufacturer's instructions (TA cloning kit; Invitrogen, Carlsbad, CA). Plasmids were purified (QIAprep Spin Miniprep kit; Qiagen Inc., Valencia, CA) and cut with EcoRI (Promega Corp., Madison, WI) to check for appropriate inserts, and 10 clones from each of the 16 original RT-PCRs were selected for sequencing in both directions using an

TABLE 2. Aphid transmission of four SY568 subisolates from sweet orange to sweet orange by single or multiple melon aphids (Aphis gossypii)

\begin{tabular}{|c|c|c|c|c|}
\hline Exp. no. ${ }^{a}$ & $\begin{array}{c}\text { No. of aphids } \\
\text { per plant }\end{array}$ & $\begin{array}{l}\text { Inoculum } \\
\text { source }^{b}\end{array}$ & $\begin{array}{c}\text { No. positive/ } \\
\text { no. inoculated }\end{array}$ & $\begin{array}{r}\text { Transmission } \\
\text { frequency }(\%)\end{array}$ \\
\hline \multirow[t]{3}{*}{1} & 30 & $1 \mathrm{~B}$ & $10 / 20$ & 50 \\
\hline & 30 & $11 \mathrm{~A}$ & $6 / 14$ & 43 \\
\hline & 30 & $18 \mathrm{~A}$ & $3 / 10$ & 30 \\
\hline \multirow[t]{2}{*}{2} & 30 & $1 \mathrm{~B}$ & $2 / 10$ & 20 \\
\hline & 30 & $18 \mathrm{~A}$ & $3 / 12$ & 25 \\
\hline \multirow[t]{3}{*}{3} & 1 & $1 \mathrm{~B}$ & $4 / 260$ & 1.5 \\
\hline & 10 & $1 \mathrm{~B}$ & $2 / 25$ & 8 \\
\hline & 30 & $1 \mathrm{~B}$ & $5 / 20$ & 25 \\
\hline
\end{tabular}

a Experiments 1, 2, and 3 were conducted in spring, fall, and summer, respectively.

${ }^{\mathrm{b}}$ Citrus tristeza virus (CTV) inoculum sources were SY568 subisolates obtained by graft transmission.

${ }^{c}$ CTV infection was detected by enzyme-linked immunosorbent assay tests using polyclonal and monoclonal (MCA13) antibodies.
ABI 3730 xl DNA Analyzer (Applied Biosystems Inc., Foster City, CA). Sequences were aligned using the CLC Sequence Viewer 6.0.2 (CLC Bio). Resulting consensus sequences were compared with each other as well as CTV isolates SY568, T30, T36, VT, T385, and NUagA using BLAST analyses (available online from the National Center for Biotechnology Information, http://blast.ncbi.nlm.nih.gov/Blast.cgi).

\section{RESULTS}

Aphid transmission. Aphid transmissibility among the three subisolates of SY568 (1B, 11A, and 18A) was variable between experiments and the number of viruliferous aphids $(n=1,10$, or 30) used (Table 2). The maximum level of transmission occurred in the first experiment when 30 aphids per plant were used with plants $1 \mathrm{~B}, 11 \mathrm{~A}$, and $18 \mathrm{~A}$ registering 50,43 , and $30 \%$ transmission efficiency, respectively. Both subisolates $1 \mathrm{~B}$ and 18A exhibited lower transmission efficiencies in additional experiments (20 to $25 \%$ ) (Table 2). The transmission efficiency was proportional to the number of aphids used per plant. When 1, 10. or 30 aphids were used, subisolate $1 \mathrm{~B}$ was transmitted at $1.5,8$, and $25 \%$, respectively (Table 2). Each of the seedlings that became infected by aphid transmission was given a designation to reflect the inoculum source from which it was derived, followed by an "a" to denote aphid transmission, followed by the replication number, (e.g., 1B-a4).

A summary of the isolates that were fully characterized throughout this article is shown in Table 3. To simplify further descriptions, "mild" will be used to describe asymptomatic isolates and "severe" will be used to describe those that induce at least moderate levels of stem pitting and stunting with or without vein corking in sweet orange seedlings. The three subisolates used as inoculum sources gave positive reactions to both the polyclonal antibody $(\mathrm{Ab})$ and the monoclonal $\mathrm{Ab}$ MCA13 when tested by ELISA. All sweet orange seedlings that were detected as CTVinfected after aphid inoculation gave positive reactions to the polyclonal $\mathrm{Ab}$; however one of the plants, 1B-a4, was negative for MCA13 while all others were positive. Plant 1B-a4 was obtained from the first aphid-transmission experiment using $1 \mathrm{~B}$ as the inoculum source with 30 aphids. Although subisolate $1 \mathrm{~B}$ was used as the inoculum source in additional multiple- (10 or 30$)$ and single-aphid transmission experiments, no other recovered subisolates were nonreactive to MCA13.

RPA analyses, cloning, and sequencing of aphid-transmitted subisolates. An initial screening by RPA was done on the aphidtransmitted subisolates from $1 \mathrm{~B}, 11 \mathrm{~A}$, and $18 \mathrm{~A}$ in order to determine genetic variation among them using probes representing the 5' UTR, p65, and CP genomic regions of isolate SY568. All controls (probes alone with and without RNase treatment and

TABLE 3. Characteristics of selected aphid transmitted subisolates and their inoculum sources showing segregation of symptoms in those from source 1B

\begin{tabular}{|c|c|c|c|c|c|}
\hline Source $^{\mathrm{a}}$ & Symptoms ${ }^{b}$ & Reactivity ${ }^{c}$ & $\begin{array}{l}\text { Aphid-transmitted } \\
\text { subisolates }\end{array}$ & Symptoms in sweet orange & $\begin{array}{c}\text { Reactivity } \\
\text { with MCA } 13^{\mathrm{d}}\end{array}$ \\
\hline $1 \mathrm{~B}$ & Moderate stunting, stem pitting; mild vein corking/clearing & MCA $13+$ & $\begin{array}{l}\text { 1B-a4 } \\
1 \mathrm{~B}-\mathrm{a} 10 \\
1 \mathrm{~B}-\mathrm{a} 17\end{array}$ & $\begin{array}{l}\text { Asymptomatic } \\
\text { (mild vein clearing in ML only) } \\
\text { Severe stunting, stem pitting, and } \\
\text { vein corking } \\
\text { Moderate stunting, stem pitting, } \\
\text { traces of vein corking }\end{array}$ & $\begin{array}{l}+ \\
+\end{array}$ \\
\hline $11 \mathrm{~A}$ & Severe stem pitting, stunting; no vein corking/clearing & MCA $13+$ & $\begin{array}{l}11 \mathrm{~A}-\mathrm{a} 1 \\
11 \mathrm{~A}-\mathrm{a} 5\end{array}$ & $\begin{array}{l}\text { Same as } 11 \mathrm{~A} \text { source } \\
\text { Same as } 11 \mathrm{~A} \text { source }\end{array}$ & $\begin{array}{l}+ \\
+\end{array}$ \\
\hline $18 \mathrm{~A}$ & Mild stem pitting, no stunting; mild vein corking, no clearing & MCA $13+$ & $\begin{array}{l}18 \mathrm{~A}-\mathrm{a} 4 \\
18 \mathrm{~A}-\mathrm{a} 6\end{array}$ & $\begin{array}{l}\text { Same as } 18 \mathrm{~A} \text { source } \\
\text { Same as } 18 \mathrm{~A} \text { source }\end{array}$ & $\begin{array}{l}+ \\
+\end{array}$ \\
\hline
\end{tabular}

a Inoculum source.

b Symptoms in sweet orange.

c Reactivity to MCA 13 antibody in enzyme-linked immunosorbent assay.

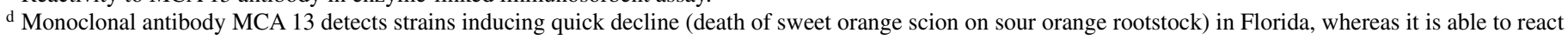
with most isolates that cause stem pitting and seedling yellows in California regardless of whether it also induces quick decline. 
probes hybridized to their respective complement transcripts) were as expected. For the $5^{\prime}$ UTR probe, only subisolate $1 \mathrm{~B}-\mathrm{a} 4$ (symptomless, MCA13 negative), failed to protect the probe, which was completely degraded (Fig. 1, lane 1B-a4). A pattern with a fully protected band and other minor bands also present in the complement control lane was seen for all the other samples tested, a typical result for severe isolates (Fig. 1). When the CP probe was used, subisolate $1 \mathrm{~B}-\mathrm{a} 4$ again had a unique pattern with little or no probe protection, whereas all other aphid-transmitted subisolates had a pattern identical to that of the original SY568 isolate (data not shown).

When analyzing RPA data produced using the p65 probe (a heat-shock protein homolog which acts as a minor structural protein) $(48,49)$, it is important to note that our previous research has shown that this probe was obtained from the putative mild strain of CTV within the SY568 isolate, whereas all other probes represent more severe strains or variants within the isolate (55). Therefore, using the p65 probe is useful for detecting single as well as mixed infections of mild and severe strains within a CTV isolate. When a mild strain is present, a fully protected portion of probe is seen at the top of the pattern, whereas severe strains that share less sequence similarity with the mild strain are represented by a pattern of smaller probe fragments lower in the gel based on data obtained from known mild and severe strains of CTV (D. Mathews, unpublished data). Thus, infections composed of a mild strain alone, a mixed infection of mild and severe strains, as well as severe strains or variants alone can all be detected using the p65 probe. However, based on previous research using this probe, the putative mild strain in isolate SY568 has never been recovered by itself, without the presence of more severe strains, when graft transmission was used (53).

Prior RPA analysis using the p65 probe identified subisolate $1 \mathrm{~B}$ (intermediate symptoms) as a mixed infection with the proposed mild strain and one or more "severe" strains, and subisolates 11A

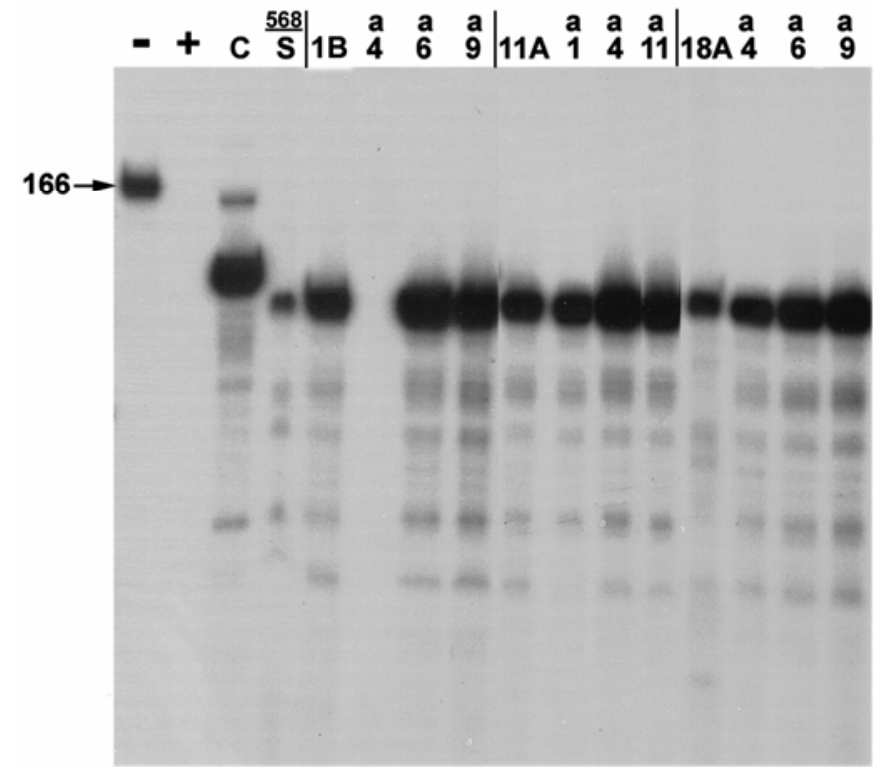

Fig. 1. RNase protection assay analysis of selected aphid-transmitted Citrus tristeza virus subisolates using the $5^{\prime}$ untranslated region probe. Note that $1 \mathrm{~B}-$ a4 provided no protection to the probe from RNase degradation, indicating significant divergence from other isolates shown that provided full protection. Controls were probe alone without RNase treatment $(-)$, probe alone with RNase treatment (+), probe hybridized to plus-sense complement RNA transcript with RNase treatment $(\mathrm{C})$, and probe hybridized to RNA from parental isolate SY568 in sweet orange, with RNase treatment (568-S). Hybridization and subsequent RNase treatment was performed on representative aphidtransmitted subisolates from inoculum sources 1B (1B, -a4, -a6, and -a9), 11A (11A, -a1, -a4, and -a11), and 18A (18A, -a4, -a6, and -a9). Size of full-length probe, including nonviral nucleotides, is shown on left margin (166). (severe symptoms) and 18A (mild to moderate symptoms) as not having detectable amounts of the putative mild strain. Using the p65 probe to analyze several aphid-transmitted subisolates from the above three source isolates, three different profiles were produced, one of which had never been seen in any other SY568derived subisolate. Inoculum source 1B had the p65 RPA pattern of a small amount of fully protected probe (common to known mild isolates) in addition to a lower fragmentation pattern (common to known severe isolates), indicating a mixed infection of a mild strain and one or more severe variants (Fig. 2, lane 1B). Of the 23 aphid-transmitted subisolates obtained from $1 \mathrm{~B}, 3$ had the same mixed-infection pattern seen in the inoculum source (Fig. 2, lanes 1B-a17 and -19); 19 had only the lower fragmentation pattern (Fig. 2, lanes 1B-a6 and -a9), apparently losing or significantly reducing the strain able to fully protect the probe; and 1 (Fig. 2, lane $1 \mathrm{~B}-\mathrm{a} 4)$, had only the fully protected fragment, losing the strains that usually produce the lower fragmentation pattern. Inoculum sources $11 \mathrm{~A}$ and $18 \mathrm{~A}$ and all of their aphid-transmitted subisolates had the same p65 profile consisting of only the lower fragmentation pattern in the gel that represents one or more severe strains with no additional segregation detected (Fig. 2). Each of the three source inocula and several of the aphid-transmitted subisolates from source $1 \mathrm{~B}$ were cloned and sequenced for nucleotide comparisons. When comparing the p65HSP region, obvious sequence differences were apparent that correlated well with the RPA data. From inoculum source 1B, two distinct sequence variants were recovered, one that had the highest sequence identities with known mild strains ( 7 of 10 clones, type 1) and one that had high

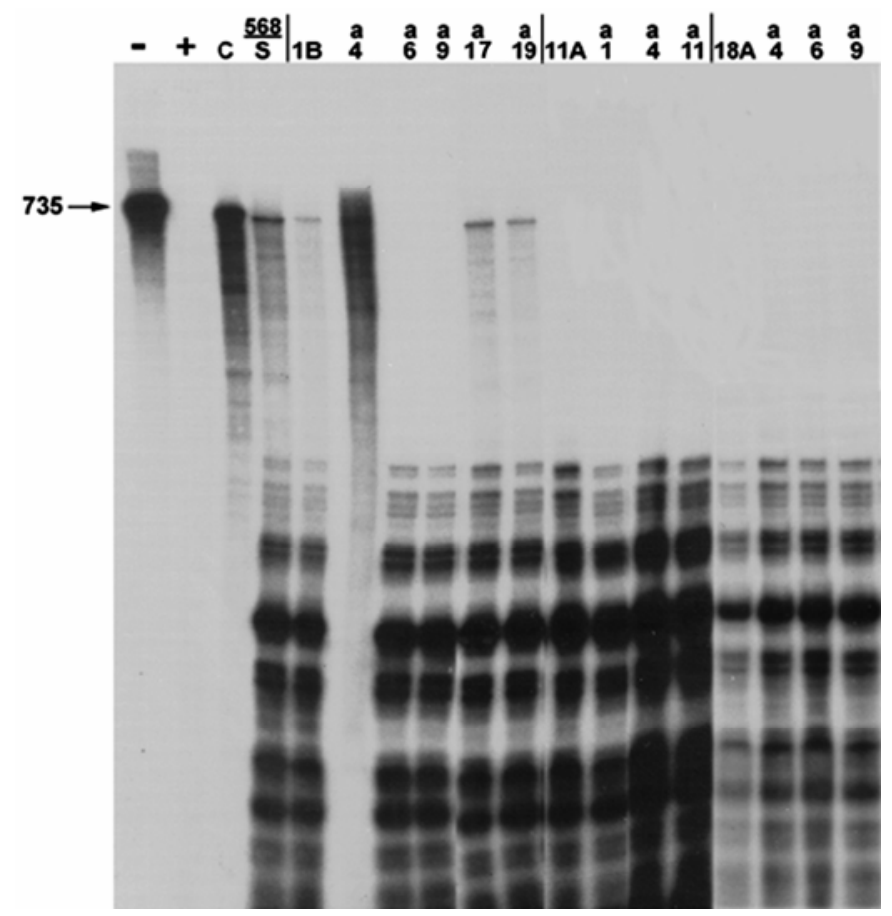

Fig. 2. RNase protection assay analysis of representative aphid-transmitted Citrus tristeza virus subisolates using the p65 heat-shock protein homolog probe showing segregation of two major sequence types. Fully protected segments near the 735-nucleotide marker using this probe indicate sequence identities with known mild strains, and smaller fragments forming the uniform pattern share sequence identities with known severe strains. Isolates with both types of patterns indicate mixed infections of mild and severe strains. Controls were probe alone without RNase treatment $(-)$, probe alone with RNase treatment $(+)$, probe hybridized to plus-sense complement RNA transcript with RNase treatment $(\mathrm{C})$, and probe hybridized to RNA from parental isolate SY568 in sweet orange with RNase treatment (568-S). Hybridization and subsequent RNase treatment was performed on aphid-transmitted subisolates from inoculum sources 1B (1B, -a4, -a6, -a9, -a17, and -a19), 11A (11A, -a1, $-\mathrm{a} 4$, and -a11), and 18A (18A, -a4, -a6, and -a9). Size of full-length probe, including nonviral nucleotides, is shown on left margin (735). 
identities with severe strains (3 of 10 clones, type 2) (Table 4). This same result was obtained when sequencing clones from aphid-transmitted subisolate 1B-a17 (derived from 1B) except that the type 2 clones were predominant ( 7 of 10 clones). Notably, RPA analysis predicted the presence of mixed mild and severe infections in both of these isolates. Sequences from mild isolate $1 \mathrm{~B}-\mathrm{a} 4$ were all of type 1 , sharing the most similarity with other known mild strains such as T385 and T30, whereas all sequences from $1 \mathrm{~B}-\mathrm{a} 10$ were of type 2 and were most similar to known severe isolates (e.g., VT and NUagA) (Table 4). Again, RPA had predicted that $1 \mathrm{~B}-\mathrm{a} 4$ and $1 \mathrm{~B}-\mathrm{a} 10$ were single populations of mild and severe strains, respectively. When each of these aphidtransmitted subisolates were compared with each other, all of the type 1 sequences were identical and all the type 2 sequences were identical. Type 1 and type 2 varied at 59 individual locations and shared only $90 \%$ sequence identity, the same percentage seen when comparing either type 1 with known severe strains or type 2 with known mild strains (Table 4). Arising from these changes was a unique EcoRI restriction site approximately in the middle of the studied p65HSP region which could be used to screen clones as being of either type 1 or 2 . All clones from the other two source isolates, 11A and 18A, predicted by RPA to contain only severe variants, were identical to the type 2 sequences above (= severe).

In order to look for genetic evidence that multiple severe variants exist within isolate SY568 that could be separated by aphid transmission, a second screening using six other available RPA probes was done. Based on the results from the p65 probe, several aphid-transmitted subisolates known to be infected with one or more severe strains only (no mild) were selected from the 1B, 11A, and 18A transmissions. All 10 of these aphid-derived subisolates were tested using the 5A (polyprotein), RdRp, CPm, p13, p20, and 3' UTR probes. Three banding patterns were resolved using the $5 \mathrm{~A}$ probe. All aphid-derived subisolates from $1 \mathrm{~B}$ and two of those from 18A presented a common profile seen previously using this probe (Fig. 3A). A similar pattern with the addition of one extra prominent band seen in subisolate 11A was also seen in the three aphid-transmitted 11A subisolates (Fig. 3A, lanes 11A-IS, -a1, -a5, and -a11). A third profile was seen for subisolate 18A-a4, which consisted of a low titer of a fully protected fragment at the top with two prominent intermediate molecular weight fragments located $\approx 1$ and $2 \mathrm{~cm}$ below the top, respectively (Fig. 3A, lane 18A-a4). This result was confirmed by repeating the test twice using new TNA preparations extracted from the infected plant. However, upon sequencing of 10 selected RT-PCR clones each, both of these changes seen in the RPAs for
$11 \mathrm{~A}$ and $18 \mathrm{~A}-\mathrm{a} 4$ were found to be the result of only a single nucleotide change, although it was consistent for all 10 clones from each isolate, indicating a stable variant population.

Analysis with the RdRp probe showed two different profiles. One aphid-transmitted subisolate from 18A (18A-a6) had a single unique band within its pattern, which otherwise resembled the common pattern seen in the other nine selected aphid-derived subisolates from 1B, 11B, and 18A (Fig. 3B). Both of these patterns were previously observed in other graft-transmitted subisolates from SY568 (data not shown). Again, when sequenced, this change in the RPA profile of subisolate 18A-a6 was due to a single nucleotide change found in all 10 clones. When using four other RPA probes, the results were identical for all 10 selected subisolates, their inoculum sources, and SY568 positive controls, with no differentiation seen (data not shown).

Based on the RPA results presented above, at least five identifiable variants of CTV were believed to exist within the SY568 isolate, one mild and four severe. Three of these were segregated only by aphid transmission while two had been previously seen through the use of graft transmission. The p65, RdRp, and 5A probes were all useful in identifying these variants. By sequencing, however, three of the severe variants were shown to be due to simple, single nucleotide changes, leaving two distinct strains, one mild and one severe, represented by sequence types 1 and 2 , respectively, within the p65HSP region.

Biological indexing. The mild (1B-a4) and one of the severe (1B-a10) subisolates derived from 1B were indexed on Mexican lime, Eureka lemon, Standard sour orange, Madam Vinous sweet orange, and Duncan grapefruit. 1B-a4 caused no symptoms in any of the five different citrus hosts, except for a very mild vein clearing in some young Mexican lime leaves. All plants gave a positive reaction for the polyclonal $\mathrm{Ab}$ and were negative for MCA13. Conversely, dramatic effects were caused by subisolate 1B-a10, which had been chosen for its lack of a detectable amount of the mild strain and its ability to cause relatively severe symptoms in the initial aphid transmissions to sweet orange. Vein clearing was visible on sweet orange, Mexican lime, sour orange, and lemon as early as 27 dpi in some replications. Later, Mexican lime and grapefruit also showed severe stunting, intense vein corking, and stem pitting. Madam Vinous sweet orange developed chlorosis with a moderate degree of stunting, vein corking, and stem pitting. Standard sour orange had minor chlorosis, stunting, and stem pitting. All 1B-a10 plants were positive for both the polyclonal $\mathrm{Ab}$ and MCA13 in ELISA.

Two plants of each citrus species in the host range inoculated with $1 \mathrm{~B}-\mathrm{a} 4$ or $1 \mathrm{~B}-\mathrm{a} 10$ were selected for RPA analysis 4 months

TABLE 4. Sequence comparisons of the p65 heat-shock protein (p65HSP) region (nucleotides 13,225-13,878 of isolate SY568) of subisolates derived from SY568 both by graft and aphid transmission to six well-characterized isolates of Citrus tristeza virus (CTV)a

\begin{tabular}{|c|c|c|c|c|c|c|}
\hline \multirow[b]{3}{*}{ CTV strain, origin ${ }^{b}$} & \multicolumn{6}{|c|}{ Nucleotide identity within the p65HSP region (\%) } \\
\hline & \multicolumn{2}{|c|}{$1 \mathrm{~B}$ source ${ }^{\mathrm{c}}$} & \multirow[b]{2}{*}{$1 \mathrm{~B}-\mathrm{a} 4^{\mathrm{d}}$} & \multirow[b]{2}{*}{$1 \mathrm{~B}-\mathrm{a} 10^{\mathrm{d}}$} & \multicolumn{2}{|c|}{$1 \mathrm{~B}-\mathrm{a} 17^{\mathrm{e}}$} \\
\hline & Type 1 & Type 2 & & & Type 1 & Type 2 \\
\hline T30, Florida & 99 & 90 & 99 & 90 & 99 & 90 \\
\hline T36, Florida & 95 & 91 & 95 & 91 & 95 & 91 \\
\hline VT, Israel & 90 & 97 & 90 & 98 & 90 & 98 \\
\hline T385, Spain & 98 & 90 & 99 & 90 & 99 & 90 \\
\hline
\end{tabular}

${ }^{a}$ Subisolates 1B (graft transmitted) and 1B-a17 (aphid transmitted) each had two different sequence variants, type 1 and type 2 , which varied in their relatedness to each standard isolate.

${ }^{\mathrm{b}}$ SY568 (source of all isolates described in this article, GenBank accession no. AF001623) causes stem pitting, stunting, and seedling yellows on various hosts; T30 is a mild strain (GenBank accession no. AF26065); T36 causes quick decline on sweet/sour combinations (GenBank accession no. AY170468); VT is a severe seedling yellows strain (GenBank accession no. EU937519); T385 is virtually asymptomatic on all hosts except mild vein clearing on Mexican lime (GenBank accession no. Y18420) (similar to aphid-transmitted subisolate 1B-a4 presented here); and NUagA is a severe isolate causing seedling yellows, stem pitting, and stunting (GenBank accession no. AB046398).

${ }^{\mathrm{c}}$ In all, 7 of 10 clones from isolate $1 \mathrm{~B}$ were of type 1 whereas 3 of 10 clones were type 2.

${ }^{\mathrm{d}}$ Individual consensus sequences derived from 10 clones each of $1 \mathrm{~B}-\mathrm{a} 4$ and $1 \mathrm{~B}-\mathrm{a} 10$, respectively.

${ }^{\mathrm{e}}$ In all, 3 of 10 clones from isolate 1B-a17 were of type 1, whereas 7 of 10 clones were type 2 . 
after inoculation, using nine different probes representing the CTV SY568 genome. Results were always consistent for each subisolate, presenting one banding pattern for $1 \mathrm{~B}-\mathrm{a} 4$ and a distinctly different pattern for $1 \mathrm{~B}-\mathrm{a} 10$, identical to those seen for each isolate in previous experiments. Patterns for each respective probe were also identical regardless of the host species used. Based on the intensity of the bands in the RPA patterns, 1B-a10 achieved a higher titer than $1 \mathrm{~B}-\mathrm{a} 4$ in every host species tested (data not shown). Additionally, the titer of both subisolates appeared suppressed in Standard sour orange and Eureka lemon, significantly so for $1 \mathrm{~B}-\mathrm{a} 4$. In order to confirm this, ELISA was done on each plant in the host range. The actual titer of $1 \mathrm{~B}-\mathrm{a} 4$ was 62 to $79 \%$ less than that of $1 \mathrm{~B}-\mathrm{a} 10$ in each host except sweet orange, where only an $8 \%$ reduction was seen (Table 5). ELISA also confirmed that Eureka lemon and Standard sour orange were the least suitable hosts for these subisolates, especially 1B-a4, where the titer was an average of 55\% lower than in the other three hosts. $1 \mathrm{~B}-\mathrm{a} 4$ was of sequence type 1 and $1 \mathrm{~B}-\mathrm{a} 10$ was of type 2 from above.

Graft-inoculated mixed infections. Three different subisolates obtained by aphid transmission from the same source (1B) were graft transmitted to sweet orange seedlings in various combinations to look at their interactions in mixed infections. The selected subisolates were 1B-a4, mild strain only (symptomless, sequence type 1); 1B-a10 (severe strains only, sequence type 2); and 1B-a17, a naturally occurring mixed infection with the mild and one or more severe strains based on prior RPA analysis using the p65 probe and sequencing (types 1 and 2). These combinations resulted in mixed infections with either one part mild (1Ba4) plus one part severe (1B-a10) or two parts mild (one each from $1 \mathrm{~B}-\mathrm{a} 4$ and $1 \mathrm{~B}-\mathrm{a} 17)$ plus one part severe (1B-a17). Controls consisted of each subisolate singly inoculated. Infection was confirmed by ELISA 30 dpi. Variation in growth was seen among the different treatments, with plants singly infected with subisolate 1B-a4 being the tallest while plants infected with subisolate $1 \mathrm{~B}-\mathrm{a} 10$ were the most stunted (Table 6). Only minor differences were seen in the heights of plants with mixed infections of mild and severe strains, whether they were naturally occurring (1B-a17 controls) or physically created (1B-a4 + 1Ba10 or $+1 B-a 17)$. Sweet orange plants graft inoculated with the mild subisolate 1B-a4 alone appeared symptomless. All plants inoculated with $1 \mathrm{~B}-\mathrm{a} 10$ or $1 \mathrm{~B}-\mathrm{a} 17$ in single or mixed infections showed vein clearing in leaves $26 \mathrm{dpi}$ and later developed stem pitting. Plants inoculated with 1B-a10 alone developed severe vein corking whereas only traces were found in those inoculated with 1B-a17 alone. The presence of an "extra dose" of mild strain inoculum in the $1 \mathrm{~B}-\mathrm{a} 4+1 \mathrm{~B}-\mathrm{a} 17$ plants did not appear to attenuate the symptoms caused by $1 \mathrm{~B}-\mathrm{a} 17$, which itself contains both the

TABLE 5. Double-antibody sandwich, indirect enzyme-linked immunosorbent assay (DAS-I-ELISA) absorbance values at $405 \mathrm{~nm}\left(\mathrm{~A}_{405}\right)$ of Citrus tristeza virus (CTV) mild (1B-a4) and severe (1B-a10) strains separated by aphid transmission from SY568 subisolate 1B and indexed in five different Citrus spp.

\begin{tabular}{lcc}
\hline & DAS-I-ELISA (A $\mathrm{A}_{405}$ average value $)$ \\
\cline { 2 - 3 } Host & $1 \mathrm{~B}-\mathrm{a} 10$ & $1 \mathrm{~B}-\mathrm{a} 4$ \\
\hline Duncan grapefruit & 1.872 & 0.536 \\
Mexican lime & 1.904 & 0.716 \\
Eureka lemon & 1.720 & 0.373 \\
Standard sour orange & 1.576 & 0.327 \\
Madam Vinous sweet orange & 1.906 & 1.748 \\
\hline
\end{tabular}

A

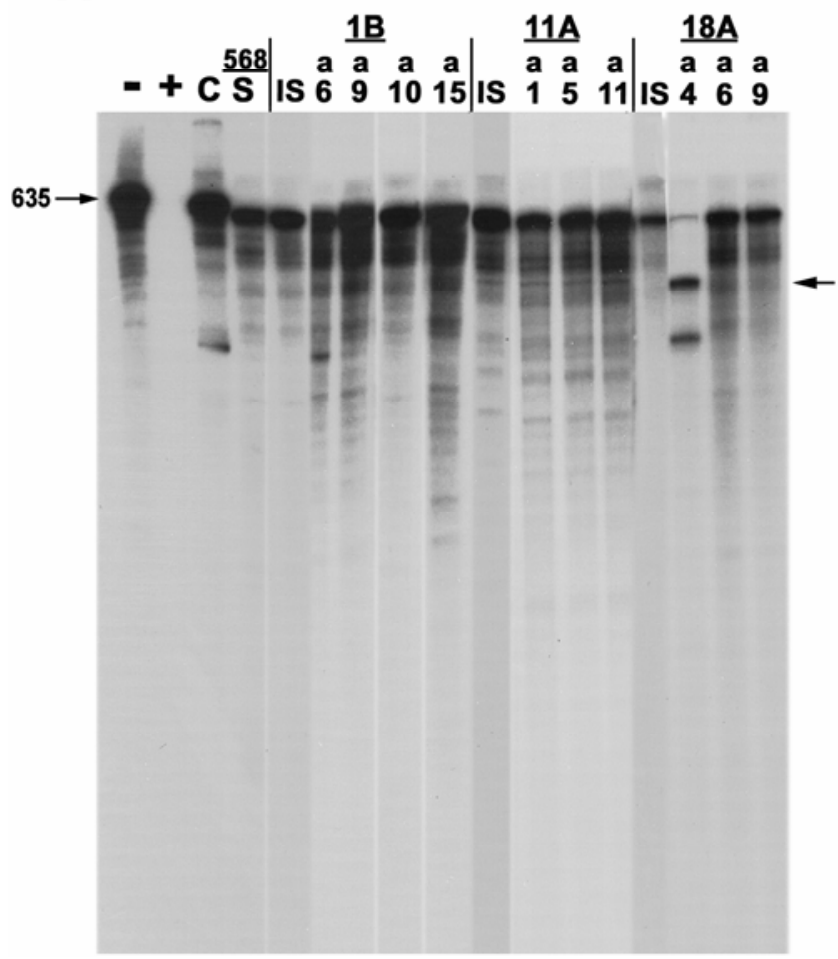

B

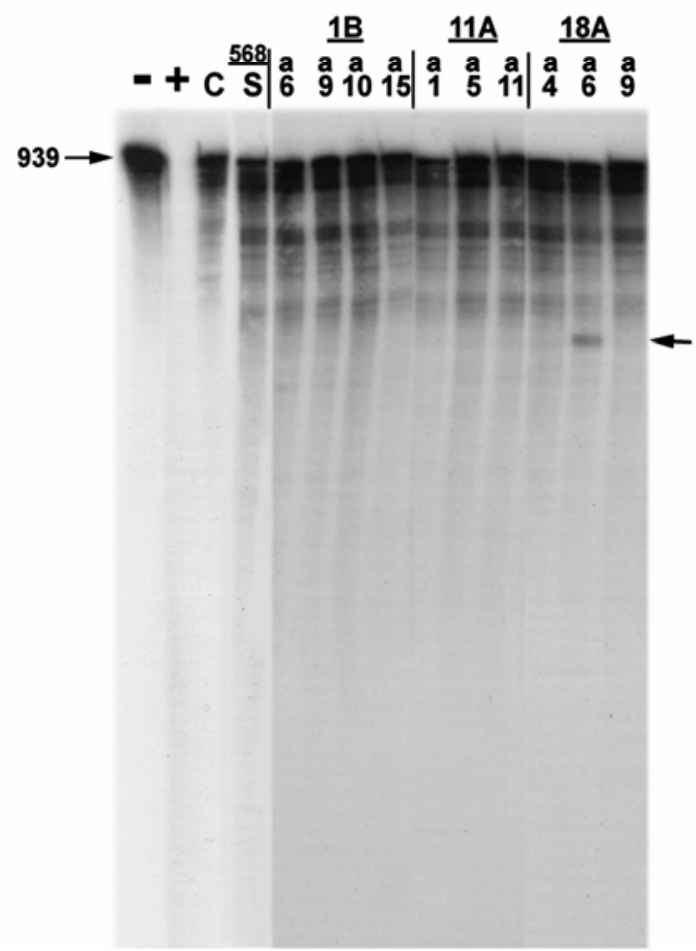

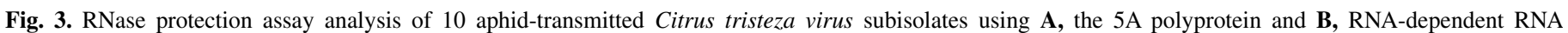

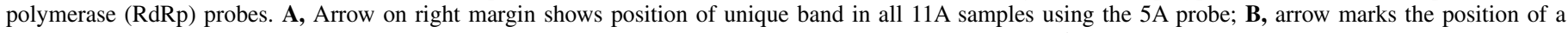

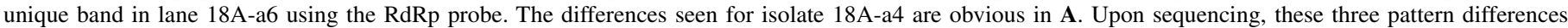

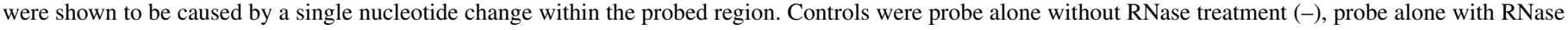

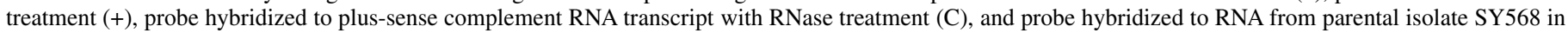

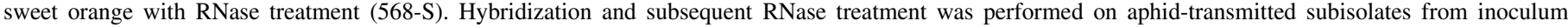

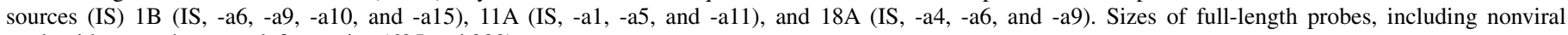
nucleotides, are shown on left margins (635 and 939). 
mild and the severe strains. However, there was attenuation of the vein corking symptom when the mild strain from $1 \mathrm{~B}-\mathrm{a} 4$ was coinoculated with the severe strains from 1B-a10, although no significant reduction in stunting was seen (Table 6).

Based on RPA using the p65 probe, mild subisolate 1B-a4 replicated well when singly inoculated on sweet orange, accumulating to a relatively high titer (Fig. 4, lanes 1B-a4, 1 and 2). However, when co-inoculated with either of the two other subisolates containing the severe variants, the titer of $1 \mathrm{~B}-\mathrm{a} 4$ was reduced to a level similar to that seen in the original SY568 isolate (Fig. 4). Additional results using the other eight RPA probes were similar to those for p65, with the mild strain 1B-a4 accumulating to a relatively high titer when in single infections whereas severe strains predominated in all mixed infections, to the point of completely masking the presence of the mild strain in most cases (data not shown).

\section{DISCUSSION}

Aphid transmission efficiencies varied from 20 to $50 \%$ depending on the season among the three SY568 subisolates when using 30 aphids per plant, a variation which is typical for CTV $(6,7,36)$. Variation in transmission by A. gossypii has been recorded since the first studies using this vector in California (13). Viral variants with different aphid transmissibilities were obtained in a study where the inoculum sources used consisted of CTV subisolates derived by graft inoculations from a single tree (40). In that study, CTV variants with frequencies of transmission $<5 \%$ to $>30 \%$ using $A$. gossypii were detected. High levels of transmission with isolate SY568 have been reported when sweet orange was the inoculum source and a different citrus species was the receptor host. Using Mexican lime and grapefruit as the recipients and 35 to 45 aphids per plant, 92 and 100\% transmission was obtained, respectively (44). The successful transmission of CTV by single aphids in 4 of 260 attempts $(1.5 \%)$ in the current study indicates that single-aphid subcultures of CTV can be obtained using A. gossypii whereas, in most studies, the more efficient CTV vector Toxoptera citricida has been used $(9,39)$.

Previous reports have shown that CTV is a complex that can occur as a mixture of strains $(9,23,41)$ and isolate SY568 fits well into this description. The presence of variants within SY568 has been confirmed by genetic and biological characterization of subisolates obtained using graft transmission $(50,53)$. More extensive characterization of an SY568 source (different than that used here) showed three major classes of CTV sequence variants: severe (most common), mild, and those which appeared to be recombinants between the other two (least common) (51). The data reported here has shown that these mild and severe sequence variants were successfully segregated using aphid transmission and now exist as independently replicating strains, the first time this has been achieved for isolate SY568. CTV has been shown to be unevenly distributed in infected plants (16); therefore, when aphids are used for transmission, they are more likely to segregate strains and modify the genetic population of the subisolates that are produced than when graft transmission is used $(1,4,8,9,16)$. Most of the segregants obtained were predicted to be severe in nature based on RPA using the p65 probe and caused some degree of stem pitting, stunting, and vein corking. However, one of these new isolates, 1B-a4, was predicted to be a mild strain. When fully characterized, 1B-a4 was symptomless on all host species and gave RPA patterns, particularly using the p65 probe, and sequence data that showed that the proposed mild strain not only existed but also had been successfully segregated through aphid transmission. Note, however, that this unique strain was obtained when using 30 aphids per plant for transmission. Single aphids were not required for its segregation from the dominant severe variants. Separation of strains with different symptomatology or pathogenicity from

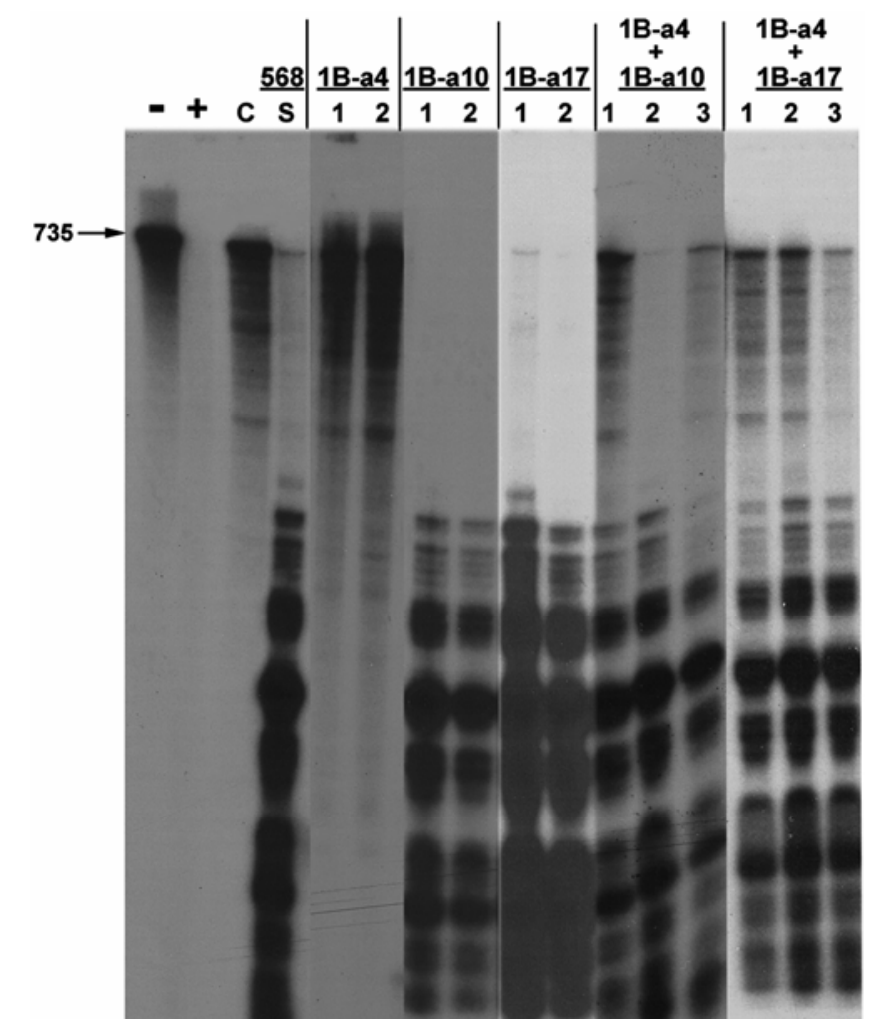

Fig. 4. Mixed infections of aphid-transmitted Citrus tristeza virus subisolates analyzed by RNase protection assay using the p65 heat-shock protein homolog probe. Three aphid-transmitted subisolates from inoculum source 1B were inoculated to sweet orange seedlings using equal doses of inoculum. Isolates were $1 \mathrm{~B}-\mathrm{a} 4,1 \mathrm{~B}-\mathrm{a} 10$, and $1 \mathrm{~B}-\mathrm{a} 17$ in single or mixed $(+)$ infections. Replications of each inoculation are shown in individual lanes (1 to 3 ). When the asymptomatic isolate 1B-a4 was inoculated into mixed infections with each of the more severe strains, its titer was reduced significantly. Controls were probe alone without RNase treatment $(-)$, probe alone with RNase treatment $(+)$, probe hybridized to plus-sense complement RNA transcript with RNase treatment (C), and probe hybridized to RNA from parental isolate SY568 in sweet orange with RNase treatment (568-S). Size of full-length probe, including nonviral nucleotides, is shown on left margin (735).

TABLE 6. Symptoms on sweet orange seedlings when graft inoculated with various combinations of Citrus tristeza virus subisolates obtained by aphid transmission from SY568 subisolate 1B

\begin{tabular}{|c|c|c|c|c|c|c|}
\hline Inoculum & No. of inoculated plants & Height range $(\mathrm{cm})$ & Average height $(\mathrm{cm})$ & Vein clearing & Vein corking & Stem pitting \\
\hline $1 \mathrm{~B}-\mathrm{a} 4^{\mathrm{a}}$ & 5 & $128-194$ & 159 & No & No & No \\
\hline $1 \mathrm{~B}-\mathrm{a} 10^{\mathrm{b}}$ & 2 & $55-57$ & 56 & Yes & Severe & Yes \\
\hline $1 \mathrm{~B}-\mathrm{a} 17^{\mathrm{c}}$ & 4 & $66-94$ & 80 & Yes & Traces & Yes \\
\hline $1 B-a 4+1 B-a 10^{d}$ & 3 & $60-65$ & 62 & Yes & Mild & Yes \\
\hline $1 \mathrm{~B}-\mathrm{a} 4+1 \mathrm{~B}-\mathrm{a} 17^{\mathrm{d}}$ & 4 & $67-88$ & 77 & Yes & Traces & Yes \\
\hline Healthy & 4 & $110-130$ & 118 & No & No & No \\
\hline
\end{tabular}

a Aphid-derived subisolate from 1B that contains a mild strain.

b Aphid-derived subisolate from 1B that contains one or more severe strains.

c Aphid-derived subisolate from 1B that contains populations of a mild and one or more severe strains (natural mixed infection).

${ }^{\mathrm{d}}$ Mixed infections physically created by graft transmission. 
that shown by their parental isolate has been detected in other studies using graft transmission $(33,34)$. Using aphid transmission, milder subisolates were obtained from four different, more severe isolates when A. gossypii was used as the vector (56). Conversely, severe subisolates that induced stem pitting on grapefruit and sweet orange were obtained using A. gossypii transmission from a mild isolate (B192) (8). Similar results have been shown using $T$. citricida as the vector $(9,35,39)$.

The p65 RPA probe and sequencing of the region proved that subisolate $1 \mathrm{~B}$ is a mixture of a mild strain with a severe strain or strains that were then successfully separated by aphid transmission. It is difficult to know whether any of the severe subcultures can truly be classed as strains or if many of them still contain a range of variants in the overall viral population. It is likely that, at a minimum, a shift in the dominance of different strains has occurred in many of the subcultures based on the RPA and sequencing results. It does appear, though, that subisolate $1 \mathrm{~B}-\mathrm{a} 4$ can be classified as an identifiable mild strain after full characterization here.

Eureka lemon and Standard sour orange have been shown to suppress CTV accumulation $(14,15)$. This effect was seen in the host range study conducted here with two different aphid-transmitted subisolates. 1B-a4 was symptomless in all five hosts while the symptoms induced by $1 \mathrm{~B}-\mathrm{a} 10$ were very similar to those reported to be caused by parental isolate SY568 $(18,20,46)$. Additional symptoms induced by $1 \mathrm{~B}-\mathrm{a} 10$ have not been previously recorded for SY568, such as severe stunting and stem pitting in Mexican lime, intense vein corking in Duncan grapefruit, and stunting and stem pitting on Standard sour orange. Collectively, these results characterize the aphid-transmitted subisolate 1B-a10 as an extraordinarily severe isolate of CTV which certainly must play a major role in the severe nature of its original parental isolate, SY568. However, because several regions of the published SY568 sequence, notably that of the p65 region, show more similarity to more recently sequenced mild strains than to known severe strain sequences, coupled with recent data showing mild, severe, and recombinants of the two exist within the SY568 population, it is difficult to assume that the published sequence is that which is totally responsible for the severe nature of the isolate.

Previous results obtained by RPA analysis using the p65 probe showed that the mild strain within SY568 is not a good competitor and was always dominated by the other severe strains present. After the mild strain (now called 1B-a4) was segregated by aphids, it was able to accumulate to levels 4 to $10 \times$ higher than when in mixed infection. When 1B-a4 was co-inoculated by grafting with other subisolates from $1 \mathrm{~B}$ that contained only severe strains (1B-a10) or naturally mixed mild and severe strains (1Ba17), the titer of the mild strain was again suppressed to previous levels. The mild strain caused little or no attenuation of severe symptoms in mixed infections. This agrees with reports indicating that the dominant viral strain in a CTV population will determine the symptom expression in infected plants (35). Sambade et al. (47) showed that severe CTV variants accumulated to higher levels than mild ones when inoculated in cross-protection type experiments. A recent report, however, suggests that minor sequence variants in a CTV population may also play a role in stem pitting and seedling yellows symptoms (11).

RPA has been used to identify a previously determined RNA sequence $(24,54)$ or to detect sequence variations in viral RNA populations $(25,29,31,42)$. It is also a valuable tool for an initial evaluation of the degree of variation in an RNA population (37) and can be used to discriminate field or experimental isolates $(2,24-26,30,31)$. In this study, nine different RPA probes obtained from cDNA clones of different genomic regions from isolate SY568 were used to determine genetic variation among aphidtransmitted subisolates of SY568, with three probes being especially valuable for this purpose. RPA results showed that
SY568 is a mixture of at least one mild and one major severe variant, with at least three other minor severe variants of CTV that are all able to replicate and survive in vivo. The p65 probe distinguished subisolates that contained a mixture of a mild strain and severe strains from those that contained only populations of the mild or severe strains alone, while the 5A and RdRp probes detected three and one different severe strains, respectively. The $5 \mathrm{~A}$ polyprotein genomic region is located in the $5^{\prime}$ region that has been reported to be the most variable in the CTV genome $(3,28)$. Yang et al. (55) showed that SY568 shared sequence similarities of 73 to $95 \%$ in the $5 \mathrm{~A}$ polyprotein region and 80 to $90 \%$ in the RdRp gene when compared with two other CTV isolates. It is interesting that the $5 \mathrm{~A}$ and $\mathrm{RdRp}$ probes identified the majority of the different severe variants because these areas are those which showed the highest number of sequence variants when comparing individual cDNA clones of SY568 (55). The RdRp and p65 genomic areas are also two of those where recombination occurred between the mild and severe variants within SY568 (51). The p65 gene has been shown to be important in virion assembly $(48,49)$ and its sequence is implicated in vector specificity for closteroviruses (22). With the dramatic differences shown here between the p65HSP sequences and RPA patterns of mild and severe strains, a role in symptom expression could also be implicated. Although RPA doesn't provide as detailed a comparison of variants as sequencing of cDNA clones, it was sufficient to identify distinct variants in the same regions previously shown to be the most variable by sequencing.

\section{LITERATURE CITED}

1. Albiach-Martí, M. R., Guerri, J., Hermoso de Mendoza, A., Laigret, F., Ballester-Olmos, J. F., and Moreno, P. 2000. Aphid transmission alters the genomic and defective RNA populations of Citrus tristeza virus isolates. Phytopathology 90:134-138.

2. Aranda, M. A., Fraile, A., García-Arenal, F., and Malpica, J. M. 1995. Experimental evaluation of the ribonuclease protection assay method for the assessment of genetic heterogeneity in populations of RNA viruses. Arch. Virol. 140:1373-1383.

3. Ayllón, M. A., López, C., Navas-Castillo, J., Garnsey, S. M., Guerri, J., Flores, R., and Moreno, P. 2001. Polymorphism of the $5^{\prime}$ terminal region of Citrus tristeza virus (CTV) RNA: Incidence of three sequence types in isolates of different origin and pathogenicity. Arch. Virol. 146:27-40.

4. Ayllón, M. A., Rubio, L., Moya, A., Guerri, J., and Moreno, P. 1999. The haplotype distribution of two genes of citrus tristeza virus is altered after host change or aphid transmission. Virology 255:32-39.

5. Bar-Joseph, M., and Lee, R. F. 1989. Citrus tristeza virus. AAB Descriptions of Plant Viruses. No. 353. Commonw. Mycol. Inst./Assoc. Appl. Biol. Wellesbourne, Warwick, UK.

6. Bar-Joseph, M., and Loebenstein, G. 1973. Effects of strain, source plant, and temperature on the transmissibility of citrus tristeza virus by the melon aphid. Phytopathology 63:716-720.

7. Bar-Joseph, M., Raccah, B., and Loebenstein, G. 1977. Evaluation of the main variables that affect citrus tristeza virus transmission by aphids. Proc. Int. Soc. Citricult. 3:958-961.

8. Brlansky, R. H., Damsteegt, V. D., Howd, D. S., and Roy, A. 2003. Molecular analyses of Citrus tristeza virus subisolates separated by aphid transmission. Plant Dis. 87:397-401.

9. Broadbent, P., Brlansky, R. H., and Indsto, J. 1996. Biological characterization of Australian isolates of citrus tristeza virus and separation of subisolates by single aphid transmissions. Plant Dis. 80:329-333.

10. Calavan, E. C., Harjung, M. K., Blue, R. L., Roistacher, C. N., Gumpf, D. J., and Moore, P. W. 1980. Natural spread of seedling yellows and sweet orange and grapefruit stem pitting tristeza viruses at the University of California, Riverside. Pages 69-75 in: Proc. Eighth Conf. Int. Organ. Citrus Virologists. E. C. Calavan, S. M. Garnsey, and L. W. Timmer, eds. IOCV, Riverside, CA.

11. Cerni, S., Ruscic, J., Nolasco, G., Gatin, Z., Krajacic, M., and Skoric, D. 2008. Stem pitting and seedling yellows symptoms of Citrus tristeza virus infection may be determined by minor sequence variants. Virus Genes 36:241-249.

12. Cevik, B., Pappu, S. S., Pappu, H. R., Benscher, D., Irey, M., Lee, R. F., and Niblett, C. L. 1996. Application of bi-directional PCR to citrus tristeza virus: detection and strain differentiation. Pages 17-24 in: Proc. 13th Conf. Int. Organ. Citrus Virologists. J. V. da Graça, P. Moreno, and R. K. Yokomi, eds. IOCV, Riverside, CA. 
13. Dickson, R. C., Johnson, M. M., Flock, R. A., and Laird, E. F., Jr. 1956. Flying aphid populations in southern California citrus groves and their relation to the transmission of the tristeza virus. Phytopathology 46:204210.

14. Dodds, J. A., Jarupat, T., Lee, G. L., and Roistacher, C. N. 1987. Effects of strain, host, time of harvest, and virus concentration on double-stranded RNA analysis of citrus tristeza virus. Phytopathology 77:442-447.

15. Dodds, J. A., Jarupat, T., Roistacher, C. N., and Lee, J. G. 1987. Detection of strain specific double-stranded RNAs in citrus species infected with citrus tristeza virus: a review. Phytophylactica 19:131-137.

16. d'Urso, F., Ayllón, M. A., Rubio, L., Sambade, A., Hermoso de Mendoza, A., Guerri, J., and Moreno, P. 2000. Contribution of uneven distribution of genomic RNA variants of citrus tristeza virus (CTV) within the plant to change in the viral population following aphid transmission. Plant Pathol. 49:288-294.

17. Garnsey, S. M., and Cambra, M. 1991. Enzyme-linked immunosorbent assay (ELISA) for citrus pathogens. Pages 193-216 in: GraftTransmissible Diseases of Citrus. Handbook for Detection and Diagnosis. International Organization of Citrus Virologists and Food and Agriculture Organization of the United Nations, Rome.

18. Garnsey, S. M., Civerolo, E. L., Gumpf, D. J., Yokomi, R. K., and Lee, R. F. 1991. Development of a worldwide collection of citrus tristeza virus isolates. Pages 113-120 in: Proc. 11th Conf. Int. Organ. Citrus Virologists. R. H. Brlansky, R. F. Lee, and L. W. Timmer, eds. IOCV, Riverside, CA.

19. Gillings, M., Broadbent, P., Indsto, J., and Lee, R. 1993. Characterization of isolates and strains of citrus tristeza closterovirus using restriction analysis of the coat protein gene amplified by the polymerase chain reaction. J. Virol. Methods 44:305-317.

20. Jarupat, T. 1990. Nucleic acid analysis of citrus tristeza virus strains: Identification, interaction, attenuation, cross-protection, and hybridization. Ph.D. dissertation, University of California-Riverside, Department of Plant Pathology, Riverside.

21. Kano, T., and Koizumi, M. 1991. Separation of citrus tristeza virus (CTV) serotypes through aphid transmission. Pages 82-85 in: Proc. 11th Conf. Int. Organ. Citrus Virologists. R. H. Brlansky, R. F. Lee, and L. W. Timmer, eds. IOCV, Riverside, CA.

22. Karasev, A. V. 2000. Genetic diversity and evolution of closterovirus. Annu. Rev. Phytopathol. 38:293-324.

23. Kong, P., Rubio, L., Polek, M., and Falk, W. B. 2000. Population structure and genetic diversity within California Citrus tristeza virus (CTV) isolates. Virus Genes 21:139-145.

24. Kurath, G., and Palukaitis, P. 1989. Satellite RNAs of cucumber mosaic virus: Recombinants constructed in vitro reveal independent functional domains for chlorosis and necrosis in tomato. Mol. Plant-Microbe Interact. 2:91-96.

25. Kurath, G., and Palukaitis, P. 1989. RNA sequence heterogeneity in natural populations of three satellite RNAs of cucumber mosaic virus. Virology 173:231-240.

26. Kurath, G., Rey, M. E. C., and Dodds, J. A. 1992. Analysis of genetic heterogeneity within the type strain of satellite tobacco mosaic virus reveals several variants and a strong bias for a $G$ to A substitution mutations. Virology 189:233-244.

27. Lee, R. F., and Bar-Joseph, M. 2000. Tristeza. Pages 61-63 in: Compendium of Citrus Diseases, second edition. L. W. Timmer, S. M. Garnsey, and J. H. Graham, eds. American Phytopathological Society Press, St. Paul, MN.

28. López, C., Ayllón, M. A., Navas-Castillo, J., Guerri, J., Moreno, P., and Flores, R. 1998. Molecular variability of the 5'- and 3'-terminal regions of citrus tristeza virus RNA. Phytopathology 88:685-691.

29. López-Galíndez, G., López, G. A., Melero, A. J., de la Fuente, L., Martínez, C., Ortíz, J., and Perucho, M. 1988. Analysis of genetic variability and mapping of point mutations in influenza virus by RNase A mismatch cleavage method. Proc. Natl. Acad. Sci. USA 85:3522-3526.

30. Mathews, D. M. 1992. Strains, field studies, and characterization of the $6.8 \mathrm{~K}$ open reading frame of satellite tobacco mosaic virus. Ph.D. dissertation, University of California-Riverside, Department of Plant Pathology, Riverside.

31. Mathews, D. M., and Dodds, J. A. 1998. Naturally occurring variants of satellite tobacco mosaic virus. Phytopathology 88:514-519.

32. Mathews, D. M., Riley, K., and Dodds, J.A. 1997. Comparison of detection methods for citrus tristeza virus in field trees during months of nonoptimal titer. Plant Dis. 81:525-529.

33. Moreno, P., Guerri, J., Ballester-Olmos, J. F., Albiach, R., and Martínez, M. E. 1993. Separation and interference of strains from a citrus tristeza virus isolate evidenced by biological activity and double-stranded RNA (dsRNA) analysis. Plant Pathol. 42:35-41.

34. Moreno, P., Guerri, J., Ballester-Olmos, J. F., Fuertes-Polo, R., Albiach, R., and Martínez, M. 1993. Variations in pathogenicity and double stranded RNA (dsRNA) patterns of citrus tristeza virus isolate induced by host passage. Pages 8-15 in: Proc. 12th Conf. Int. Organ. Citrus
Virologists. P. Moreno, J. V. da Graça, and L. W. Timmer, eds. IOCV, Riverside, CA

35. Nickel, O., Santos Filho, H. P., and Vilarinhos, A. D. 1996. Segregation of citrus tristeza virus strains by graft propagation. Pages 64-70 in: Proc. 13th Conf. Int. Organ. Citrus Virologists. J. V. da Graça, P. Moreno, and R. K. Yokomi, eds. IOCV, Riverside, CA.

36. Norman, P. A., Sutton, R. A., and Burditt, A. K., Jr. 1968. Factors affecting transmission of tristeza virus by melon aphids. J. Econ. Entomol. 61:238-242.

37. Palukaitis, P., Roossinck, M. J., and García-Arenal, F. 1994. Applications of ribonuclease protection assay in plant virology. Methods Mol. Genet. 4:237-50.

38. Permar, T. A., Garnsey, S. M., Gumpf, D. V., and Lee, R. F. 1990. A monoclonal antibody that discriminates strain of citrus tristeza virus. Phytopathology 80:224-228.

39. Powell, C. A., and Lin, Y. 2005. Separation of citrus tristeza virus isolates in mixed infections through transfer by single brown citrus aphids. HortScience 40:694-696.

40. Raccah, B., Loebenstein, G., and Singer, S. 1980. Aphid-transmissibility variants of citrus tristeza virus in infected trees. Phytopathology 70:89-93.

41. Rocha-Peña, M. A., Lee, R. F., Lastra, R., Niblett, C. L., Ochoa-Corona, F. M., Garnsey, S. M., and Yokomi, R. K. 1995. Citrus tristeza virus and its aphid vector Toxoptera citricida: threats to citrus production in the Caribbean and Central and North America. Plant Dis. 79:437-445.

42. Rodríguez-Alvarado, G., Kurath, G., and Dodds, J. A. 1995. Heterogeneity in pepper isolates of cucumber mosaic virus. Plant Dis. 79:450-455.

43. Roistacher, C. N. 1981. Blueprint for disaster-part two: changes in transmissibility of seedling yellows. Citrograph 67:28-32.

44. Roistacher, C. N., and Bar-Joseph, M. 1984. Transmission of tristeza and seedling yellows tristeza by Aphis gossypii from sweet orange, grapefruit and lemon to Mexican lime, grapefruit and lemon. Pages 9-18 in: Proc. 9th Conf. Int. Organ. Citrus Virologists. S. M. Garnsey, L. W. Timmer, and J. A. Dodds, eds. IOCV, Riverside, CA.

45. Roistacher, C. N., Bar-Joseph, M., and Gumpf, D. J. 1984. Transmission of tristeza and seedling yellow tristeza virus by small populations of Aphis gossypii. Plant Dis. 68:494-496

46. Roistacher, C. N., Dodds, J. A., and Bash, J. A. 1988. Cross protection against citrus tristeza seedling yellows and stem pitting viruses by protective isolates developed in greenhouse plants. Pages 91-100 in: Proc. 10th Conf. Int. Organ. Citrus Virologists. L. W. Timmer, S. M. Garnsey, and L. Navarro, eds. IOCV, Riverside, CA.

47. Sambade, A., Ambros, S., Lopez, C., Ruiz-Ruiz, S., Hermoso de Mendoza, A., Flores, R., Guerri, J., and Moreno, P. 2007. Preferential accumulation of severe variants of citrus tristeza virus in plants coinoculated with mild and severe variants. Arch. Virol. 152:1115-1126.

48. Satyanarayana, T., Gowda, S., Ayllon, M. A., and Dawson, W. O. 2004. Closterovirus bipolar virion: Evidence for initiation of assembly by minor coat protein and its restriction to the genomic RNA 5' region. Proc. Natl. Acad. Sci. USA 101:799-804.

49. Satyanarayana, T., Gowda, S., Mawassi, M., Albiach-Marti, M. R., Ayllon, M. A., Robertson, C., Garnsey, S. M. and Dawson, W. O. 2000. Closterovirus encoded HSP70 homolog and p61 in addition to both coat proteins function in efficient virion assembly. Virology 278:253-265.

50. Velaqzquez-Monreal, J. J. 2003. Diversity among isolates of Citrus tristeza virus with an emphasis on severe strains. Ph.D. dissertation, University of California-Riverside, Department of Plant Pathology, Riverside.

51. Vives, M. C., Rubio, L., Sambada, A. Mirkov, T. E., Moreno, P., and Guerri, J. 2005. Evidence of multiple recombination events between two RNA sequence variants within a citrus tristeza virus isolate. Virology 331:232-237.

52. Williams, A. P. 1997. Detection of diversity within a single strain (SY568) of the citrus tristeza closterovirus. M.Sc. thesis, University of CaliforniaRiverside, Department of Plant Pathology, Riverside.

53. Williams, A. P., Mathews, D. M., Heick, J. A., and Dodds, J. A. 2002. Segregation of sweet orange stem pitting types and stunting factors in subcultures from the severe SY568 strain of Citrus tristeza virus. Pages 21-30 in: Proc. 15th Conf. Int. Organ. Citrus Virologists. N. Durán-Vila, R. G. Milne, and J. V. da Graça, eds. IOCV, Riverside, CA.

54. Winter, E., Yamamoto, F., Almoguera, C., and Perucho, M. 1985. A method to detect and characterize point mutations in transcribed genes: amplification and overexpression of the mutant c-ki-ras allele in human tumor cells. Proc. Natl. Acad. Sci. USA 82:7575-7579.

55. Yang, Z., Mathews, D. M., Dodds, J. A., and Mirkov, T. E. 1999. Molecular characterization of an isolate of citrus tristeza virus that causes severe symptoms in sweet orange. Virus Genes 19:131-142.

56. Yokomi, R. K., Garnsey, S. M., Civerolo, E. L., and Gumpf, D. J. 1989. Transmission of citrus tristeza virus isolates by a Florida colony of Aphis gossipii. Plant Dis. 73:552-556. 